\title{
PENGARUH LINGKUNGAN FISIK ORGANISASI (SERVICESCAPE) TERHADAP KEPUTUSAN MENGUNJUNGI MUSEUM NEGERI SRI BADUGA BANDUNG
}

\author{
Bambang Widjajanta \\ Ginna Indah Wulan Avrianti
}

\begin{abstract}
Abstrak
Dewasa ini industri pariwisata merupakan industri terbesar dalam perekonomian. Sektor pariwisata menjadi salah satu penggerak utama perekonomian di Indonesia. Indonesia sebagai negara yang kaya akan objek wisatanya menargetkan kunjungan wisatawan sebesar tujuh juta orang pada tahun 2007 dengan pencapaian devisa sebesar 5,4 milliar dollar USA. Pariwisata saat ini merupakan sektor kegiatan berorientasi ekspor terbesar kedua setelah migas. Rendahnya tingkat kunjungan di Museum Negeri Sri Baduga ditandai dengan mulai jarangnya pengunjung yang tertarik untuk berkunjung ke museum. Dikarenakan hal tersebut maka Museum Negeri Sri Baduga Bandung harus membuat beberapa langkah untuk dapat meraih jumlah pengunjung yang lebih, sehingga dapat bersaing dengan industri yang sejenis. Upaya yang dilakukan adalah dengan cara memberikan/menawarkan lingkungan fisik organisasi (servicescape) yang lebih baik sehingga memotivasi masyarakat untuk mau mengunjungi museum. Tujuan dari penelitian ini adalah untuk memperoleh temuan mengenai tanggapan responden terhadap lingkungan fisik organisasi (servicescape) Museum Negeri Sri Baduga Bandung; Untuk memperoleh temuan mengenai tingkat kunjungan di Museum Negeri Sri Baduga Bandung; dan Untuk mengetahui besarnya pengaruh lingkungan fisik organisasi (servicescape) terhadap kunjungan di Museum Negeri Sri Baduga Bandung.

Berdasarkan variabel yang diteliti maka jenis penelitian ini adalah penelitian deskriptif dan verifikatif. Jangka Waktu penelitian bersifat cross sectional method. Populasi penelitian ini adalah pengunjung Museum Sri Baduga Bandung berjumlah 93.403 orang. Berdasarkan teknik penarikan sampel secara systematic random sampling dengan menggunakan rumus Slovin diperoleh sampel sebesar 250 sampel. Teknik pengumpulan data dilakukan dengan studi literatur, observasi, wawancara, dan kuesioner. Pengujian hipotesis dilakukan dengan menggunakan analisis regresi linear sederhana.

Hasil penelitian menunjukkan lingkungan fisik organisasi (servicescape) Museum Negeri Sri Baduga Bandung menurut pengunjung berkategori sedang. Indikator yang berkontribusi paling tinggi ialah air quality, sedangkan indikator yang memiliki kontribusi paling rendah ialah design exterior. Keputusan untuk mengunjungi Museum Negeri Sri Baduga Bandung menurut sebagian besar pengunjung sangat rendah dengan indikator yang memiliki kontribusi paling tinggi berupa frekuensi dan yang memberikan kontribusi paling rendah ialah indikator pilihan nama museum. Hasil lainnya menunjukkan adanya pengaruh signifikan dari lingkungan fisik organisasi (servicescape) terhadap keputusan untuk mengunjungi Museum Negeri Sri Baduga Bandung.
\end{abstract}

\section{Kata Kunci: Lingkungan Fisik Organisasi dan Keputusan Mengunjungi}

\section{PENDAHULUAN}

Dewasa ini industri pariwisata merupakan industri terbesar dalam perekonomian bersamaan dengan perkembangan industri telekomunikasi dan teknologi informasi. Sektor pariwisata menjadi penyumbang terbesar dalam perdagangan internasional dan menjadi salah satu penggerak utama perekonomian dunia bersama dengan industri telekomunikasi dan teknologi informasi, hal ini diungkapkan oleh World Tourism and Trade Center (WTTC).
Indonesia merespon pernyataan WTTC dengan menetapkan target baru kunjungan wisman sebesar tujuh juta orang pada tahun 2007 dengan pencapaian devisa sebesar 5,4 miliar dolar AS. Badan Pusat Statistik (BPS) mencatat bahwa pariwisata Indonesia saat ini merupakan sektor kegiatan berorientasi ekspor terbesar kedua setelah migas yang menghasilkan penerimaan devisa tertinggi yang pernah dicapai sebesar 6,7 miliar US\$ (BPS,2005) namun perolehan tinggi ini tidak berkesinambungan untuk tahun berikutnya 


\section{StrategiC}

hal ini disebabkan industri pariwisata nasional sedang mengalami berbagai gangguan keamanan.

Pembangunan kebudayaan dan pariwisata tahun 2007 dilakukan dengan melihat tolak ukur pembangunan bidang kebudayaan dan pariwisata yang termuat dalam dokumen Program Pembangunan Nasional (PROPENAS) 2006-2007 yang selanjutnya menjadi tolok ukur dalam kerangka pembangunan kebudayaan dan pariwisata nasional.

Mengingat pembangunan kebudayaan dan pariwisata nasional merupakan bagian integral dan berkesinambungan, maka pembangunan di kedua sektor tersebut menjalankan dua program pembangunan yaitu: program pelestarian dan pengembangan kebudayaan serta program pengembangan pariwisata.

Provinsi Jawa Barat terdiri dari banyak kota yang salah satu diantaranya adalah kota Bandung yang juga merupakan ibukota dari provinsi tersebut. Kota Bandung pun memiliki banyak sekali objek wisata dari mulai wisata alam, wisata heritage (gedung- gedung bersejarah) dan wisata budaya (museum).

Kota Bandung sebagai ibukota dari provinsi Jawa Barat merupakan kota yang penuh akan sejarah oleh karena itu di kota ini banyak didirikan museum sebagai tempat untuk menyimpan bendabenda bersejarah yang berkaitan dengan kota Bandung maupun seputar wilayah Jawa Barat

Museum merupakan sebuah institusi yang terbuka untuk masyarakat dan telah berkembang sejak 2,5 abad lalu. Sebagai produk dari masa Humanisme Renaissance, yaitu masa pencerahan abad 18. Sebelumnya, museum dikenal dengan istilah Cabinet Curioussity atau lemari benda aneh dan disajikan untuk lingkungan yang terbatas (golongan bangsawan). Disebut juga Chamber of Wonder, satu ruang kecil tempat bermain para pangeran, kaum bangsawan dan gereja yang jarang terbuka untuk umum.

Seiring berkembangnya waktu, fungsi museum mengalami perubahan sesuai zamannya. Museum kini menbuka diri untuk kepentingan masyarakat sesuai dengan fungsinya. Fungsi tersebut lebih dipertegas memalui Peraturan Pemerintah (PP) Republik Indonesia No. 19 tahun 1995; bahwa museum merupakan lembaga tempat penyimpanan, perawatan, pengamanan dan pemanfaatan benda-benda bukti material hasil budaya manusia serta alam dan lingkungannya guna menunjang upaya perlindungan dan pelestarian kekayaan budaya bangsa.

Perkembangan museum di Indonesia semakin pesat pada tahun 1980-an. Munculnya museummuseum swasta dan pendirian museum negeri di setiap provinsi, termasuk pendirian museum di provinsi Jawa Barat khususnya kota Bandung.

Tabel 1 di bawah ini menyajikan data mengenai beberapa museum yang ada di Kota Bandung.

Tabel 1

Nama-Nama Museum di Kota Bandung

\begin{tabular}{|c|l|l|}
\hline No & Nama Museum & Alamat \\
\hline 1 & Museum Geologi & Jl. Diponegoro No. 57 \\
\hline 2 & Museum Siliwangi & Jl. Lembong \\
\hline 3 & $\begin{array}{l}\text { Museum Sri } \\
\text { Baduga }\end{array}$ & Jl. BKR No 185 \\
\hline 4 & Museum Asia Afrika & Jl. Asia Afrika \\
\hline 5 & $\begin{array}{l}\text { Museum Pos } \\
\text { Indonesia }\end{array}$ & Jl. Cilaki \\
\hline 6 & Museum Yayasan & Jl. Geusan Ulun \\
\hline
\end{tabular}

Sumber: Disbudpar Kabupaten/Kota di Jawa Barat

Berdasarkan data tersebut, diketahui bahwa terdapat beberapa Museum di Kota Bandung. Data kunjungan wisatawan ke museum di kota Bandung secara lebih rinci dapat dilihat pada tabel berikut: Tabel 2

Data Kunjungan Ke Museum di Kota Bandung Tahun 2007

\begin{tabular}{|c|c|c|c|c|c|}
\hline \multirow[t]{2}{*}{ No } & \multirow[t]{2}{*}{$\begin{array}{c}\text { Nama } \\
\text { Museum }\end{array}$} & \multirow[t]{2}{*}{$\begin{array}{l}\text { Jenis } \\
\text { Museum }\end{array}$} & \multicolumn{2}{|c|}{$\begin{array}{c}\text { Jumlah } \\
\text { Pengunjung } \\
\text { Museum }\end{array}$} & \multirow[t]{2}{*}{$\begin{array}{c}\text { Total } \\
\text { Pengunjung }\end{array}$} \\
\hline & & & Wisnus & Wisman & \\
\hline 1 & $\begin{array}{l}\text { Margasatwa } \\
\text { Taman Sari }\end{array}$ & Khusus & 656.870 & 28 & 656.896 \\
\hline 2 & Geologi & Khusus & 138.601 & 1.453 & 140.054 \\
\hline 3 & Sri Baduga & Umum & 80.420 & 99 & 80.512 \\
\hline 4 & $\begin{array}{l}\text { Konferensi } \\
\text { Asia Afrika }\end{array}$ & Khusus & 28.915 & 1.583 & 30.498 \\
\hline 5 & $\begin{array}{l}\text { Pos } \\
\text { Indonesia }\end{array}$ & Khusus & 16.863 & 91 & 16.954 \\
\hline 6 & Barli & Khusus & 4.621 & 354 & 4.975 \\
\hline
\end{tabular}

Berdasarkan data tabel di atas, diketahui bahwa pada tahun 2007 Museum Negeri Sri Baduga berada di peringkat ketiga dalam hal perolehan jumlah pengunjung museum di kota Bandung. Museum Negeri Sri Baduga merupakan museum negeri provinsi Jawa Barat yang berada di bawah Dinas Kebudayaan dan Pariwisata (DisbudPar) provinsi Jawa Barat mengalami satu masalah yakni terjadi penurunan pada jumlah pengunjungnya. Hal ini terbukti pada Tabel 3 di halaman beriktunya. 
Tabel 3

Total Jumlah Pengunjung Museum Negeri Sri Baduga dari Tahun 2005-2007

\begin{tabular}{|c|c|c|c|r|r|r|r|r|r|r|}
\hline TAHUN & \multicolumn{1}{|c|}{ TK } & \multicolumn{1}{c|}{ SD } & \multicolumn{1}{c|}{ SLTP } & \multicolumn{1}{c|}{ SLTA } & MHSISWA & \multicolumn{1}{c|}{ WISMAN } & PENELITI & \multicolumn{1}{c|}{ UMUM } & P.KHUSUS & JUMLAH \\
\hline 2005 & 1.036 & 23.909 & 26.189 & 11.420 & 1.370 & 116 & 1.520 & 14.261 & 57.998 & 137.819 \\
\hline 2006 & 1.578 & 19.970 & 24.643 & 10.511 & 1.301 & 94 & 1.013 & 8.528 & 48.883 & 114.521 \\
\hline 2007 & 1.041 & 16.958 & 10.155 & 10.155 & 137 & 99 & 894 & 8.097 & 32.983 & 80.519 \\
\hline
\end{tabular}

Sumber: Badan Pengelolaan Museum Negeri Sri Baduga

Berdasarkan tabel 1.3 dapat di lihat bahwa pada tahun 2005 jumlah pengunjung cukup tinggi yaitu berjumlah 137.819 pengunjung, yang merupakan akumulasi dari jenjang TK sampai ke pengunjung pameran khusus. Namun terjadi penurunan jumlah pengunjung pada tahun 2006 yaitu sebesar 114.521 pengunjung, dan yang lebih mengkhawatirkan ternyata pada tahun berikutnya mengalami penurunan yang cukup drastis, jumlah pengunjungnya hanya berjumlah 80.519 pengunjung yang berarti jika dipersentasikan terjadi penurunan sekitar 20\%. Hal ini tentu merupakan suatu hal yang sangat diluar dugaan mengingat penurunan yang terjadi pada tahun sebelumnya tidaklah cukup besar.

Kurangnya minat tiap orang untuk berkunjung ke museum atau citra museum itu sendiri yang terkesan kurang menarik atau membosankan membuat tiap individu enggan untuk berkunjung ke museum. Hal ini tentu dapat merugikan museum itu sendiri. Kurangnya informasi yang diperoleh oleh masyarakat akan program dari museum diduga juga turut berpengaruh terhadap menurunnya jumlah pengunjung Museum Negeri Sri Baduga.

Lingkungan fisik organisasi (servicescape) merupakan salah satu strategi perusahaan jasa, dimana layanan diciptakan dan penyedia jasa dengan pelanggan berinteraksi, ditambah unsurunsur berwujud yang ada dan dipakai untuk berkomunikasi atau untuk mendukung peran jasa. Dimensi dari bauran jasa seperti lingkungan fisik organisasi (servicescape) yang menyertai pemasaran jasa pada konsumen akan mempengaruhi konsumen dalam keputusan pembelian.

Keputusan pembelian suatu produk atau jasa dilakukan dengan pertimbangan semua alternatif dan memilih alternatif yang dapat memberikan hasil maksimum. Berdasarkan riset yang dilakukan pada pengunjung Museum Sri Baduga dapat diperoleh beberapa faktor yang mempengaruhi menurunnya jumlah pengunjung. Namun dari banyaknya faktor yang ada terdapat faktor utama yang sangat mempengaruhinya yaitu lingkungan fisik organisasi (servicescape) dari museum itu sendiri. Hal ini terjadi karena museum merupakan suatu industri pariwisata yang salah satunya menggunakan lingkungan fisik organisasi (servicescape) untuk menarik minat masyarakat sehingga diharapkan dapat meningkatkan minatnya untuk mau berkunjung ke Museum Negeri Sri Baduga.

Konsep paling mendasar yang melandasi pemasaran adalah kebutuhan dan keinginan individu. Dari sinilah akan tercipta suatu permintaan. Dalam hal ini pemasaran berperan untuk melakukan kegiatan pertukaran guna memuaskan dan memenuhi kebutuhan atau keinginan tersebut, sehingga dapat dikatakan pemasaran merupakan suatu kegiatan untuk menciptakan pertukaran.

Konsep pemasaran menegaskan bahwa kesuksesan sebuah organisasi dalam mewujudkan tujuannya sangat dipengaruhi oleh kemampuannya dalam mengidentifikasi kebutuhan dan keinginan pelanggan sasarannya dan memberikan kepuasan yang diharapkan secara lebih efektif dan efisien daripada pesaingnya. Kebutuhan pelanggan dipengaruhi oleh karakteristik pribadi dan karakteristik fisik lingkungan. Sementara itu, keinginan pelanggan dipengaruhi oleh konteks individual dan konteks lingkungan.

Konsep pemasaran ini berkembang dalam organisasi atau perusahaan jasa yang dikenal dengan nama pemasaran jasa yaitu merupakan penerapan konsep pemasaran yang dalam sistem distribusi atau penyalurannya bersifat langsung dari produsen ke konsumen. Di dalam pemasaran jasa terdapat tujuh bauran pemasaran, salah satunya adalah lingkungan fisik organisasi (servicescape) yang memegang peranan penting dalam usaha jasa pariwisata. Fandi Tjiptono dalam pemasaran jasa (2006: 32) menyatakan bahwa: Lingkungan fisik organisasi (servicescape) diartikan sebagai suatu karakteristik intangible pada jasa yang menyebabkan pelanggan potensial 


\section{StrategiC}

tidak bisa menilai suatu jasa sebelum mengkonsumsinya."

Menurut pengertian tersebut, dapat dikatakan bahwa lingkungan fisik organisasi (servicescape) bisa menyebabkan resiko yang di persepsikan konsumen dalam keputusan pembelian semakin besar. Oleh sebab itu, salah satu unsur penting dalam bauran pemasaran adalah upaya untuk mengurangi tingkat resiko tersebut dengan jalan menawarkan lingkungan fisik dari karakteristik jasa. Lingkungan fisik ini bisa dalam berbagai bentuk salah satunya dekorasi internal dan eksternal yang atraktif. Setelah melakukan penawaran lingkungan fisik diharapkan masyarakat yang sebelumnya tidak mengetahui penawaran atau keberadaan Museum ini dapat mengetahui secara jelas sehingga masyarakat yang sebelumnya tidak mau berkunjung dapat berubah pikiran dengan ketertarikannya untuk mau mengunjungi Museum. Itu semua artinya perilaku, sikap dan nilai masyarakat berubah ke arah yang di inginkan.

Bagi industri jasa pariwisata seperti museum, pengunjung merupakan salah satu unsur paling penting karena walau bagaimanapun juga museum sangat menggantungkan hidupnya pada pengunjung.

Berdasarkan uraian diatas, sudah sepantasnya Museum Negeri Sri Baduga mampu menerapkan suatu penawaran lingkungan fisik lingkungan fisik organisasi (servicescape)) yang efektif dan efisien juga sesuai dengan kebutuhan masyarakat sehingga diharapkan dapat meningkatkan tanggapan terhadap perusahaan (Museum) di mata masyarakat. Berdasarkan hal tersebut maka penulis perlu melakukan penelitian dengan rumusan masalah sebagai berikut:

1. Bagaimana tanggapan responden terhadap lingkungan fisik organisasi (servicescape) Museum Negeri Sri Baduga Bandung

2. Bagaimana tingkat kunjungan di Museum Negeri Sri Baduga Bandung

3. Seberapa besar pengaruh lingkungan fisik organisasi (servicescape) baik secara simultan maupun parsial terhadap kunjungan di Museum Negeri Sri Baduga Bandung.

\section{KERANGKA PEMIKIRAN}

Persaingan yang semakin kuat, menyebabkan setiap perusahaan yang ingin memenangkan persaingan ataupun dapat bertahan di tuntut untuk menciptakan sebuah keunggulan kompetitif salah satunya lewat pemasaran, yang dilaksanakan sebagai suatu cara untuk menarik dan meningkatkan loyalitas konsumen. Di dunia bisnis, marketing diartikan sebagai "kegiatan bisnis fenomena perdagangan".

Menurut Kotler dan Keller (2006:6), pemasaran merupakan fungsi organisasi dan satu set proses untuk menciptakan, mengkomunikasikan, dan menyampaikan nilai kepada pelanggan serta untuk membangun hubungan pelanggan yang memberikan keuntungan bagi organisasi dan pihak-pihak yang berkepentingan terhadap organisasi.

Keunggulan kompetitif dalam pemasaran dapat dilakukan perusahaan dengan melakukan kegiatan penawaran jasa dan Marketing Mix, sehingga dapat menciptakan suatu ouput produk (program) yang berkualitas yang sesuai dengan kebutuhan dan keinginan konsumen. Orientasi pemasaran dari input saat ini berpengaruh besar pada persaingan tiap perusahaan oleh karena itu pemasaran suatu produk (program) haruslah diperhatikan.

Menurut Buchari Alma (2004:205) Marketing Mix atau bauran pemasaran adalah seperangkat alat pemasaran yang digunakan perusahaan untuk mencapai tujuan pemasaran dalam pemasaran sasaran. Dimana bauran pemasaran memiliki empat komponen penting, yaitu: Produk, Promotion, Price and Place.

Hal lainnya dikemukakan oleh Kotler (2005:17) bahwa "Marketing Mix adalah seperangkat alat pemasaran yang digunakan perusahaan untuk terus-menerus mencapai tujuan pemasarannya di pasar sasaran"

Marketing mix pemasaran jasa hampir sama dengan Marketing mix pemasaran biasa, terdiri dari faktor-faktor yaitu yang disebut $4 \mathrm{P}$, namun menurut Kotler dalam Fandy Tjiptono (2003:31) menyatakan bahwa Marketing mix pemasaran jasa perlu ditambahkankan 3P lagi. Faktor-faktor tersebut dapat dijabarkan sebagai berikut :
1. Product
2. Pricing
3. Promotion
4. Place
5. People
6. Physical Evidence
7. Process 


\section{StrategiC}

Dalam pemasaran jasa, Marketing Mix sangat berperan dalam pencapaian tujuan dari perusahaan (museum), salah satu diantaranya adalah melalui physical evidence. Physical evidence sendiri merupakan karakteristik baik tangible maupun intangible pada jasa menyebabkan pelanggan potensial tidak bisa menilai suatu jasa sebelum mengkonsumsinya.physical evidence terdiri dari dua unsur yaitu service encounter (moment of truth) dan lingkungan fisik organisasi (servicescape). Dalam penelitian ini yang akan dibahas adalah mengenai lingkungan fisik organisasi (servicescape) merupakan lingkungan fisik dimana jasa disampaikan dan dimana perusahaan dan konsumennya berinteraksi, serta setiap komponen tangible yang memfasilitasi penampilan yang dipakai untuk berkomunikasi atau mendukung peran jasa tersebut (Yazid, 2005:20).

Dimensi lingkungan fisik organisasi (servicescape) yang dikaji dalam penelitian ini terdiri dari:

1. Facility exterior (fasilitas eksterior) terdiri dari:

a. Exterior design (desain eksterior), sesuatu yang ditawarkan perusahaan (museum) melalui desain bangunan gedung untuk menarik minat pengunjung.

b. Parking (parkir), sebuah layanan dalam bentuk kawasan bagi pengunjung untuk menyimpan kendaraannya.

c. Landscape (kawasan), kawasan tempat museum dan

d. Surrounding environment (lingkungan sekitar), keadaan lingkungan yang ada di sekitar museum.

2. Facility interior (fasilitas interior) terdiri dari:

a. Interior design (desain interior), sesuatu yang ditawarkan perusahaan (museum) melalui desain didalam ruangan.

b. Equipment (peralatan), benda-benda yang digunakan untuk membantu terlaksananya pameran

c. Layout (tata letak), pola pengaturan bendabenda pajangan.

d. Air quality/ temperature (suhu udara), pengaturan kualitas udara didalam ruangan.

Hal ini sesuai dengan program lingkungan fisik organisasi (servicescape) yang dilakukan oleh Museum Sri Baduga Bandung. Lingkungan fisik organisasi (servicescape) merupakan lingkungan fisik perusahaan jasa dalam layanan diciptakan serta dimana penyedian jasa dan pelanggan berinteraksi ditambah unsur-unsur berwujud yang ada dan dipakai untuk mendukung peran jasa.

Museum Sri Baduga harus menunjukan keunggulan jasa mereka melalui lingkungan fisik organisasi. Suatu jasa akan menyeimbangkan suatu penampilan yang dapat diamati sebagai bukti yang dapat menarik minat konsumen untuk melakukan pembelian aktual. Pengembangan lingkungan fisik museum tersebut ditujukan untuk menyampaikan nilai yang diharapkan konsumen baik itu segi kebersihan, estetika, pengaturan lay out dan manfaat lainnya. Sikap karakteristik pembeli dan proses pengambilan keputusannya akan menimbulkan keputusan pembelian tertentu.

Sejumlah riset menunjukkan bahwa desain lingkungan fisik organisasi (servicescape) mempengaruhi pilihan pelanggan, ekspektasi pelanggan, kepuasan pelanggan dan perilaku lainnya.

Pemahaman mengenai lingkungan fisik organisasi (servicescape) sangat penting bagi Museum Sri Baduga karena bisa memainkan beberapa peranan sekaligus, yaitu package, facilitator, socializer dan differensiator. Dengan meningkatkan lingkungan fisik organisasi (servicescape) akan meningkatkan minat serta keputusan untuk mengunjungi Museum.

Keputusan untuk mengunjungi merupakan tahap dalam proses pengambilan keputusan pembelian. Pada tahap evaluasi, para konsumen atau pengunjung membentuk preferensi atas pilihan jenis serta nama-nama museum dalam kumpulan pilihan. Pengunjung juga mungkin membentuk niat untuk mengunjungi museum yang paling disukai.

Diantara niat pembelian dan keputusan mengunjungi museum yang dilakukan oleh pengunjung dan dipengaruhi oleh banyak hal berupa stimuli yang datang dari informasi mengenai koleksi museum, harga, lokasi dan promosi yang berpengaruh menyangkut masalah ekonomi keuangan, teknologi, politik, budaya dan sebagainya. Lalu konsumen akan mengolah segala informasi tersebut dan diambillah berupa respon yang muncul mengenai produk apa yang dibeli, merek, toko yang akan dipilih dan waktu pembelian.

Terdapat empat dimensi dalam keputusan untuk mengunjungi, yaitu: 
1. Pilihan koleksi museum

2. Pilihan nama museum

3. Waktu kunjungan

4. Jumlah kunjungan

Dalam program pemasaran jasa yang dilakukan oleh Museum Negeri Sri Baduga memang mengandalkan lingkungan fisik organisasi (servicescape) sebagai alat penyampai pesan kepada masyarakat. lingkungan fisik organisasi (servicescape) yang dilakukan tentu tidak selamnya berhasil, hal ini tentu saja dapat mengganggu eksistensi dari bisnis ini mengingat masyarakat akan mengenal perusahaan (Museum) dari lingkungan fisik organisasi (servicescape) yang di lakukan. Hal inilah yang menjadi dasar peneliti untuk melakukan penelitian karena apabila tidak ditemukan solusi lain dapat mengganggu atau mengancam masa depan Museum Negeri Sri Baduga.

Selanjutnya paradigman penelitian ini di jelaskan dalam bentuk gambar berikut:

\begin{tabular}{|c|c|c|}
\hline \multicolumn{2}{|c|}{$\begin{array}{l}\text { LINGKUNGAN FISIK ORGANISASI } \\
\text { (SERVICESCAPE) }\end{array}$} & $\begin{array}{l}\text { KEPUTUSAN UNTUK } \\
\text { MENGUNJUNGI }\end{array}$ \\
\hline $\begin{array}{l}\text { Facility exterior: } \\
\text { - Exterior design } \\
\text { - Parking } \\
\text { - Landscape } \\
\text { - Surrounding } \\
\quad \text { environment }\end{array}$ & $\begin{array}{l}\text { Facility interior: } \\
\text { - Interior design } \\
\text { - Equipment } \\
\text { - Layout } \\
\text { - } \quad \text { Air quality } \\
\\
\text { temperature }\end{array}$ & $\begin{array}{l}\text { 1. Pilihan Koleksi Museum } \\
\text { 2. Pilihan Nama Museum } \\
\text { 3. Waktu Kujungan } \\
\text { 4. Jumlah kunjungan }\end{array}$ \\
\hline
\end{tabular}

Gambar 1

Paradigma Penelitian

\section{METODE PENELITIAN}

Penelitian yang dilaksanakan ini menganalisis pengaruh lingkungan fisik organisasi (servicescape) terhadap keputusan untuk mengunjungi Museum Negeri Sri Baduga Bandung. Variabel bebas (independen variable/ predictor variable) yang diteliti antara lain dimensi lingkungan fisik organisasi (servicescape) (Variabel $X)$ yang meliputi beberapa dimensi, yaitu:facility eksterior (eksterior design, parking, landscape dan surrounding environment) dan facility interior (interior design, equipment, layout dan air quality/temperature).

Variabel terikat (dependent variable/predictor variable) yang diteliti adalah keputusan untuk mengunjungi (Variabel $Y$ ) yang meliputi dimensi: pilihan koleksi museum, pilihan nama museum, waktu kunjungan dan jumlah kunjngan.
Berdasarkan variabel yang diteliti maka jenis penelitian dari penelitian ini adalah penelitian deskriptif dan verifikatif. Menurut Sugiyono (2005:11), Penelitian deskriptif adalah penelitian yang dilakukan untuk mengetahui nilai variabel mandiri, baik satu variabel atau lebih (independent) tanpa membuat perbandingan, atau menghubungkan dengan variabel yang lain. Sedangkan penelitian verifikatif menurut Suharsimi Arikunto (2003:7) ialah penelitian yang pada dasarnya ingin menguji kebenaran melalui pengumpulan data di lapangan.

Metode penelitian merupakan rencana atau prosedur sistematik yang dipersiapkan agar dapat melakukan penelitian (Komaruddin Sastradipoera, 2005:29). Berdasarkan jenis penelitiannya yaitu penelitian deskriptif dan verifikatif, maka metode yang digunakan dalam penelitian ini adalah metode deskriptif survey dan metode explanatory survey untuk menjelaskan hubungan antara variabel-variabel melalui pengujian hipotesis. Metode tersebut dipergunakan untuk mempelajari pengetahuan, keyakinan, preferensi, dan kepuasan orang, serta untuk mengukur besarannya dalam populasi secara umum.

Menurut Ker Linger (Sugiyono, 2005:7), yang dimaksud dengan metode survei yaitu metode penelitian yang dilakukan pada populasi besar maupun kecil, tetapi data yang dipelajari adalah data dari sampel yang diambil dari populasi tersebut, sehingga ditemukan kejadian-kejadian relatif, distribusi, dan hubungan-hubungan antar variabel sosiologis maupun psikologis. Penelitian yang menggunakan metode ini, melakukan kegiatan pengumpulan informasi dari sebagian populasi secara langsung di tempat kejadian (empirik) dengan tujuan untuk mengetahui pendapat dari sebagian populasi terhadap objek yang sedang diteliti.

Metode pengembangan yang dipergunakan adalah cross-sectional methode. Menurut Uma Sekaran (2006:177) Cross sectional methode yaitu suatu metode penelitian yang dilakukan dengan data yang hanya sekali dikumpulkan, mungkin selama periode harian, mingguan, atau bulanan, dalam rangka menjawab pertanyaan penelitian.

Populasi adalah keseluruhan kelompok orang, peristiwa, atau hal yang peneliti investigasi (Uma Sekaran, 2006:241). Penentuan populasi harus dimulai dengan penentuan yang jelas mengenai populasi yang menjadi sasaran penelitiannya yang 


\section{StrategiC}

disebut populasi sasaran yaitu populasi yang akan menjadi cakupan kesimpulan penelitian. Jadi apabila dalam sebuah hasil penelitian dikeluarkan kesimpulan, maka menurut etika penelitian kesimpulan tersebut hanya berlaku untuk populasi sasaran yang telah ditentukan.

Populasi penelitian ini adalah pengunjung Museum Sri Baduga yang berjumlah 93.403 orang. Sampel dalam penelitian ini adalah sebagian dari populasi penelitian, yaitu sebagian dari pengunjung Museum negeri Sri Baduga yang berjumlah 93.403 orang. Jumlah sampel minimal yang diteliti berjumlah 250 orang. Ukuran sampel ini diperoleh berdasarkan hasil perhitungan dengan menggunakan rumus Slovin (Husein Umar, 2003:141)

Tabel 4 di bawah ini menyajikan operasionalisasi variabel penelitian.

Tabel 4

Operasionalisasi Variabel

\begin{tabular}{|c|c|c|c|c|}
\hline $\begin{array}{l}\text { Variable/Sub } \\
\text { Variabel }\end{array}$ & Konsep variabel & Indikator & Ukuran & Skala \\
\hline $\begin{array}{l}\text { Lingkungan fisik } \\
\text { organisasi } \\
\text { (servicescape) } \\
\text { (X) }\end{array}$ & $\begin{array}{l}\text { Sesuatu hal yang nyata turut } \\
\text { mempengaruhi keputusan } \\
\text { pelanggan untuk menggunakan } \\
\text { produk jasa yang ditawarkan. }\end{array}$ & & & \\
\hline \multicolumn{5}{|l|}{ Facility exterior } \\
\hline & \multirow{2}{*}{ Exterior design } & $\begin{array}{l}\text { - Daya tarik desain bangunan } \\
\text { museum }\end{array}$ & $\begin{array}{l}\text { - Tingkat daya tarik desain } \\
\text { bangunan museum }\end{array}$ & Ordinal \\
\hline & & $\begin{array}{l}\text { - Keunikan desain bangunan } \\
\text { museum }\end{array}$ & $\begin{array}{l}\text { - Tingkat keunikan desain } \\
\text { bangunan museum }\end{array}$ & Ordinal \\
\hline & \multirow{2}{*}{ Parking } & $\begin{array}{l}\text { - Kenyamanan tempat parkir } \\
\text { museum }\end{array}$ & $\begin{array}{l}\text { - Tingkat kenyamanan tempat } \\
\text { parkir museum }\end{array}$ & Ordinal \\
\hline & & $\begin{array}{l}\text { - Kemanan tempat parkir } \\
\text { museum }\end{array}$ & $\begin{array}{l}\text { - Tingkat keamanan tempat parkir } \\
\text { museum }\end{array}$ & Ordinal \\
\hline & \multirow{3}{*}{ Landscape } & - Ketepatan lokasi museum & $\begin{array}{l}\text { - } \begin{array}{l}\text { Tingkat } \\
\text { museum }\end{array} \\
\end{array}$ & Ordinal \\
\hline & & - Kemudahan akses transportasi & $\begin{array}{l}\text { - Tingkat kemudahan akses } \\
\text { transportasi }\end{array}$ & Ordinal \\
\hline & & - Kebersihan museum & - Tingkat kebersihan museum & Ordinal \\
\hline & \multirow{2}{*}{ Surrounding environtment } & $\begin{array}{l}\text { - Kenyamanan lokasi di sekitar } \\
\text { museum }\end{array}$ & $\begin{array}{l}\text { - Tingkat kenyamanan lokasi di } \\
\text { sekitar museum }\end{array}$ & Ordinal \\
\hline & & $\begin{array}{l}\text { - Keamanan lokasi di sekitar } \\
\text { museum }\end{array}$ & $\begin{array}{l}\text { - Tingkat keamanan lokasi di } \\
\text { sekitar museum }\end{array}$ & Ordinal \\
\hline \multicolumn{5}{|l|}{ Facility interior } \\
\hline & \multirow{4}{*}{ Interior design } & $\begin{array}{l}\text { - Daya tarik desain interior } \\
\text { museum }\end{array}$ & $\begin{array}{l}\text { - Tingkat daya tarik desain } \\
\text { interior museum }\end{array}$ & Ordinal \\
\hline & & $\begin{array}{l}\text { - Kesesuaian desain interior } \\
\text { dengan benda-benda pameran }\end{array}$ & $\begin{array}{l}\text { - Tingkat kesesuaian desain } \\
\text { interior dengan benda-benda } \\
\text { pameran }\end{array}$ & Ordinal \\
\hline & & $\begin{array}{l}\text { - Keunikan desain interior } \\
\text { museum }\end{array}$ & $\begin{array}{l}\text { - Tingkat keunikan desain interior } \\
\text { museum }\end{array}$ & Ordinal \\
\hline & & $\begin{array}{l}\text { - Keindahan desain interior } \\
\text { museum }\end{array}$ & $\begin{array}{l}\text { - Tingkat keindahan desain } \\
\text { interior museum }\end{array}$ & Ordinal \\
\hline & \multirow[t]{2}{*}{ Equipment } & $\begin{array}{l}\text { - Kelengkapan alat bantu barang- } \\
\text { barang pameran. }\end{array}$ & $\begin{array}{l}\text { - Tingkat kelengkapan alat bantu } \\
\text { barang-barang pameran. }\end{array}$ & Ordinal \\
\hline & & $\begin{array}{l}\text { - Kebersihan dari barang-barang } \\
\text { pameran. }\end{array}$ & $\begin{array}{l}\text { - Tingkat kebersihan dari barang- } \\
\text { barang pameran. }\end{array}$ & Ordinal \\
\hline & \multirow[b]{2}{*}{ Layout } & $\begin{array}{l}\text { - Kerapihan penempatan benda- } \\
\text { benda pameran }\end{array}$ & $\begin{array}{l}\text { - Tingkat kerapihan penempatan } \\
\text { benda-benda pameran }\end{array}$ & Ordinal \\
\hline & & $\begin{array}{l}\text { - Kesesuaian penempatan benda- } \\
\text { benda pameran }\end{array}$ & $\begin{array}{lr}\text { - } & \text { Tingkat } \\
\text { penempatan } & \text { besesuaian } \\
\text { pameran } & \\
\end{array}$ & Ordinal \\
\hline & Air quality/temperature & $\begin{array}{l}\text { - Kesesuaian temperatur di dalam } \\
\text { museum }\end{array}$ & $\begin{array}{l}\text { - Tingkat kesesuaian temperaur } \\
\text { museum }\end{array}$ & Ordinal \\
\hline
\end{tabular}




\section{StrategiC}

\begin{tabular}{|c|c|c|c|c|}
\hline $\begin{array}{l}\text { Variable/Sub } \\
\text { Variabel }\end{array}$ & Konsep variabel & Indikator & Ukuran & Skala \\
\hline \multirow[t]{4}{*}{$\begin{array}{l}\text { Keputusan } \\
\text { untuk } \\
\text { mengunjungi } \\
\text { (Y) }\end{array}$} & $\begin{array}{l}\text { Proses keputusan untuk } \\
\text { mengunjungi adalah suatu } \\
\text { tahapan yang dilalui konsumen } \\
\text { didalam keputusan pembelian- } \\
\text { nya. Proses keputusan untuk } \\
\text { mengunjungi yang terdiri dari } \\
\text { lima tahap yaitu: pilihan koleksi } \\
\text { museum, pilihan merk, pilihan } \\
\text { penyalur, waktu kunjungan dan } \\
\text { jumlah kunjungan. (Philip Kotler } \\
\text { dan Gary Amstrong, 2000:222) }\end{array}$ & & & \\
\hline & \multirow{3}{*}{ Pilihan koleksi museum } & - Daya tarik benda pameran & $\begin{array}{l}\text { - Tingkat daya tarik benda } \\
\text { pameran }\end{array}$ & Ordinal \\
\hline & & - Kelengkapan benda pameran & $\begin{array}{l}\text { - Tingkat kelengkapan benda } \\
\text { pameran }\end{array}$ & Ordinal \\
\hline & & - Keunikan benda pameran & $\begin{array}{lll}\text { - Tingkat keunikan } & \text { benda } \\
\text { pameran } & & \\
\end{array}$ & Ordinal \\
\hline & \multirow[t]{2}{*}{ Pilihan nama museum } & $\begin{array}{l}\text { - Daya tarik nama museum "Sri } \\
\text { Baduga" }\end{array}$ & $\begin{array}{l}\text { - Tingkat daya tarik nama } \\
\text { museum "Sri Baduga" }\end{array}$ & Ordinal \\
\hline & & - Daya tarik logo museum & - Tingkat daya tarik logo museum & Ordinal \\
\hline & Waktu kunjungan & - Intensitas kunjungan & $\begin{array}{l}\text { - Tingkat intensitas kunjungan ke } \\
\text { museum }\end{array}$ & Ordinal \\
\hline & Jumlah kunjungan & - Frekuensi kunjungan & - Tingkat frekuensi kunjungan & Ordinal \\
\hline
\end{tabular}

Sumber: Diolah dari Berbagai Referensi

\section{HASIL PENELITIAN DAN PEMBAHASAN}

Hasil penelitian dan pembahasan akan disajikan secara terurut. Dimulai dengan hasil rekapitulasi skor variabel penelitian, kemudian pengujian dan pembahasan hipotesis, serta diakhiri dengan penyajian mengenai implikasi penelitian ini terhadap bidang kajian yang diteliti.

\section{REKAPITULASI SKOR VARIABEL} PENELITIAN

1. Variabel Lingkungan Fisik Organisasi

Variabel yang diteliti pada penelitian ini adalah servicescape sebagai variabel $\mathrm{X}$ yang terdiri dari: facility exterior (design eksterior, parking, landscape, surrounding environment) dan facility interior (interior design, equipment, lay out, air quality).

Penelitian ini dilakukan untuk meneliti tanggapan responden mengenai variabel-variabel tersebut melalui penyebaran kuesioner, dimana yang menjadi responden ini adalah pengunjung Museum Negeri Sri Baduga Bandung, yang terdiri dari 250 responden.

Tabel 5 di bawah ini menyajikan data hasil rekapitulasi skor lingkungan fisik (servicescape).

Tabel 5

Rekapitulasi Indikator Lingkungan Fisik Organisasi (Servicescape)

\begin{tabular}{|c|c|c|c|c|}
\hline No & Indikator & Skor & Skor ideal & $\%$ \\
\hline & Facility exterior & & & \\
\hline \multirow[t]{4}{*}{1} & Design exterior & & & \\
\hline & - $\quad$ Daya tarik desain bangunan Museum & 788 & 1250 & $63 \%$ \\
\hline & - Keunikan desain bangunan museum & 766 & 1250 & $61 \%$ \\
\hline & Total Skor & 1554 & 2500 & $62 \%$ \\
\hline \multirow[t]{4}{*}{2} & Parking & & & \\
\hline & - Tingkat kenyamanan tempat parkir & 832 & 1250 & $67 \%$ \\
\hline & - Tingkat keamanan tempat parkir & 768 & 1250 & $61 \%$ \\
\hline & Total Skor & 1600 & 2500 & $64 \%$ \\
\hline \multirow[t]{5}{*}{3} & Landscape & & & \\
\hline & - $\quad$ Ketepatan lokasi Museum & 757 & 1250 & $61 \%$ \\
\hline & - Kemudahan akses transportasi & 777 & 1250 & $62 \%$ \\
\hline & - $\quad$ Tingkat kebersihan Museum & 844 & 1250 & $68 \%$ \\
\hline & Total Skor & 2378 & 3750 & $63 \%$ \\
\hline 4 & Surrounding environment & & & \\
\hline
\end{tabular}




\begin{tabular}{|c|c|c|c|c|}
\hline No & Indikator & Skor & Skor ideal & $\%$ \\
\hline & - Kenyamanan lokasi Museum & 848 & 1250 & $68 \%$ \\
\hline & - Keamanan lokasi sekitar Museum & 764 & 1250 & $62 \%$ \\
\hline & Total Skor & 1612 & 2500 & $64 \%$ \\
\hline & Facility interior & & & \\
\hline \multirow[t]{6}{*}{5} & Design interior & & & \\
\hline & - Daya tarik desain interior Museum & 849 & 1250 & $67 \%$ \\
\hline & - $\quad$ Tingkat kesesuaian bangunan Museum dengan barang-barang pameran & 766 & 1250 & $61 \%$ \\
\hline & . Keunikan desain interior Museum & 807 & 1250 & $65 \%$ \\
\hline & - Keindahan desain interior Museum & 973 & 1250 & $78 \%$ \\
\hline & Total skor & 3395 & 5000 & $68 \%$ \\
\hline \multirow[t]{4}{*}{6} & Equipment & & & \\
\hline & - Kelengkapan alat-alat bantu benda-benda pameran & 764 & 1250 & $61 \%$ \\
\hline & - $\quad$ Tingkat kebersihan di dalam Museum & 849 & 1250 & $68 \%$ \\
\hline & Total skor & 1613 & 2500 & $65 \%$ \\
\hline \multirow[t]{4}{*}{7} & Lay out & & & \\
\hline & Tingkat kerapihan penempatan benda-benda pameran & 766 & 1250 & $61 \%$ \\
\hline & - Tingkat kesesuaian penempatan benda-benda pameran & 807 & 1250 & $65 \%$ \\
\hline & Total skor & 1573 & 2500 & $63 \%$ \\
\hline \multirow[t]{4}{*}{8.} & Air quality & & & \\
\hline & - Tingkat kesesuaian temperature di dalam Museum & 973 & 1250 & $78 \%$ \\
\hline & Total skor & 973 & 1250 & $78 \%$ \\
\hline & Total Skor Servicescape & 14698 & 22500 & $65,3 \%$ \\
\hline
\end{tabular}

Sumber : Hasil Pengolahan Data

Berdasarkan Tabel 5 menunjukkan bahwa sebagian besar responden menyatakan gambaran lingkungan fisik organisasi (servicescape) Museum Negeri Sri Baduga Bandung secara keseluruhan yaitu sebesar $65,3 \%$, secara berurutan dapat diketahui indikator-indikator lingkungan fisik organisasi (servicescape) yang dominan. Indikator yang paling dominan adalah kode etik dalam air quality/ temperature (suhu udara) di dalam Museum yaitu sebesar $78 \%$, indikator kedua adalah design interior (desain interior Museum) yaitu sebesar $68 \%$, indikator ketiga adalah equipment (peralatan) Museum yaitu sebesar $65 \%$, indikator keempat adalah parking (parkir), surrounding environment (lingkungan sekitar) Museum yaitu sebesar 64\%, indikator kelima adalah landscape (kawasan) Museum dan lay out (tata letak) penempatan benda-benda pameran sebesar $63 \%$, dan indikator yang paling rendah adalah design exterior (desain eksterior) bangunan Museum sebesar $62 \%$.

Hasil tersebut menunjukkan bahwa kode etik dalam air quality (suhu udara) dari dimensi servicescape yang dinilai oleh responden Museum Negeri Sri Baduga Bandung Bandung dapat dikatakan paling tinggi, karena sebagian besar responden yaitu sebanyak 45 orang atau sebesar
$78 \%$ dari 250 orang responden antara $60 \%$ sampai dengan $80 \%$, artinya bahwa sebagian besar responden Museum Negeri Sri Baduga Bandung menyatakan tingkat kode etik dalam kategori baik atau tinggi dalam yaitu air quality di dalam Museum dan jika di lihat dari nilai tertinggi yaitu kesesuaian temperature di dalalam Museum.

Indikator yang dominan kedua adalah interior design Museum $68 \%$ dan jika dilihat dari nilai tertinggi yaitu keindahan desain interior bangunan Museum, daya tarik desain interior Museum, keunikan desain interior desain Museum dan kesesuaian bangunan interior bangunan dengan banda-benda pameran . Indikator dominan yang ketiga adalah equipment $65 \%$ dan jika dilihat dari nilai tertinggi yaitu tingkat kebersihan di dalam Museum dan kelengkapan alat bantu benda-benda pameran.

Menurut rumus Sugiyono (2008:135), untuk mencari daerah kontinum yang menunjukkan wilayah ideal dari tanggapan responden terhadap lingkungan fisik organisasi (servicescape), maka dapat diketahui:

\section{Mencari skor ideal Lingkungan Fisik Organisasi}




\section{StrategiC}

Skor ideal $\Longrightarrow \begin{aligned} & \text { Skor Tertinggi } x \text { Jumlah Butir Item } x \\ & \text { Jumlah Pengguna }\end{aligned}$
Skor ideal $\longrightarrow 5 \times 1 \times 1250=22500$

Mencari skor Terendah Lingkungan Fisik Organisasi Skor ideal $\Longrightarrow$ Skor Terendah $x$ Jumlah Butir Item $x$ Jumlah Pengguna

Skor ideal $\longrightarrow 1 \times 1 \times 250=250$

Mencari Panjang Interval Kelas Lingkungan Fisik Organisasi

\begin{tabular}{|l} 
Panjang Interval Kelas $\rightleftarrows \begin{array}{l}\text { Skor Ideal : Banyaknya } \\
\text { Kelas Interval }\end{array}$ \\
Panjang Interval Kelas $\longrightarrow$ 22500: $5=4500$ \\
\hline
\end{tabular}

Jumlah skor tanggapan responden terhadap lingkungan fisik organisasi (servicescape) yaitu 14693, maka tanggapan 250 responden terhadap lingkungan fisik organisasi (servicescape) adalah $(14693: 22500) \times 100 \%=65,3 \%$. Hal ini secara kontinum termasuk kategori antara sedang dan tinggi, namun tepatnya lebih pada kategori sedang.

Lingkungan fisik organisasi (servicescape) merupakan lingkungan fisik dimana jasa disampaikan dan dimana perusahaan dan

konsumennya berinteraksi, serta setiap komponen tangible yang memfasilitasi penampilan yang dipakai untuk berkomunikasi atau mendukung peran jasa tersebut (Yazid, 2005:20). Jasa bersifat intangible sehingga sulit untuk dievaluasi maka lingkungan fisik memberikan tanda-tanda, misalnya bagaimana kualitas jasa tersebut.

Berdasarkan pendapat ahli pemasaran tersebut, dapat disimpulkan bahwa Servicescape (lingkungan fisik organisasi) merupakan semua bentuk fasilitas jasa untuk memperkenalkan dan mempromosikan jasa secara non personal oleh perusahaan yang jelas untuk menarik minat responden agar tertarik dan merasakan kepuasan terhadap layanan jasa yang kemudian dapat membantu perusahaan dalam meningkatkan loyalitas pada jasa yang ditawarkan.

\section{Variabel Keputusan Mengunjungi}

Berdasarkan penelitian dengan menyebarkan angket kepada 250 orang responden dapat diketahui mengenai gambaran variabel keputusan untuk mengunjungi. Rekapitulasi skor variabel keputusan mengunjungi disajikan pada Tabel 6 di bawah ini.

Tabel 6

Rekapitulasi Indikator Keputusan untuk Mengunjungi

\begin{tabular}{|c|c|c|c|c|}
\hline No & Indikator & Skor & Skor ideal & $\%$ \\
\hline \multirow[t]{5}{*}{1} & Pilihan koleksi Museum & & & \\
\hline & - Daya tarik benda-benda pameran & 785 & 1250 & $63 \%$ \\
\hline & - Kelengkapan benda-benda pameran & 790 & 1250 & $63 \%$ \\
\hline & - Keunikan benda-benda pameran & 758 & 1250 & $63 \%$ \\
\hline & Total Skor & 2333 & 3750 & $62 \%$ \\
\hline \multirow[t]{4}{*}{2} & Pilihan nama Museum & & & \\
\hline & - Tingkat daya tarik nama Museum & 760 & 1250 & $61 \%$ \\
\hline & - Tingkat daya tarik logo Museum & 764 & 1250 & $61 \%$ \\
\hline & Total Skor & 1524 & 2500 & $61 \%$ \\
\hline \multirow[t]{3}{*}{3} & Waktu kunjungan & & & \\
\hline & - Intenitas kunjungan & 788 & 1250 & $63 \%$ \\
\hline & Total skor & 788 & 1250 & $63 \%$ \\
\hline \multirow[t]{4}{*}{4} & Jumlah kunjungan & & & \\
\hline & - $\quad$ Frekuensi kunjungan & 956 & 1250 & $76 \%$ \\
\hline & Total skor & 956 & 1250 & $76 \%$ \\
\hline & Total Skor Keputusan untuk mengunjungi & 7155 & 12500 & $57 \%$ \\
\hline
\end{tabular}

Sumber : Hasil Pengolahan Data 2008

Berdasarkan Tabel 6 bahwa sebagian besar responden menyatakan gambaran keputusan untuk mengunjungi Museum Negeri Sri Baduga Bandung secara keseluruhan yaitu sebesar $57 \%$, secara berurutan dapat diketahui indikatorindikator yang dominan. Indikator paling dominan pertama yaitu berdasarkan jumlah kunjungan dengan nilai $76 \%$, indikator dominan yang kedua yaitu berdasarkan waktu kunjungan dengan nilai 


\section{StrategiC}

$63 \%$, indikator dominan ketiga yaitu berdasarkan pilihan koleksi museum dengan nilai $62 \%$ dan indikator dominan yang keempat yaitu berdasarkan pilihan nama museum dengan nilai $61 \%$.

Menurut rumus Sugiyono (2008:135), untuk mencari daerah kontinum yang menunjukkan wilayah ideal dari tanggapan responden terhadap keputusan untuk mengunjungi, maka dapat diketahui:

Mencari skor ideal Keputusan Mengunjungi

Skor ideal $\longleftrightarrow \begin{aligned} & \text { Skor Tertinggi } x \text { Jumlah Butir Item } x \\ & \text { Jumlah Pengguna }\end{aligned}$
Skor ideal $\longrightarrow 5 \times 1 \times 1250=22500$

Mencari skor Terendah Keputusan Mengunjungi

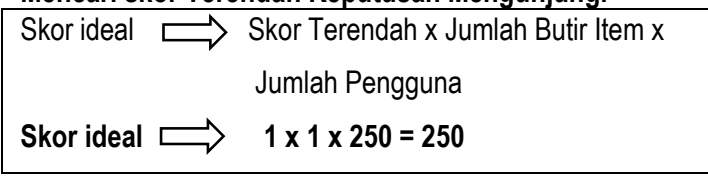

Mencari Panjang Interval Kelas Keputusan Mengunjungi

\begin{tabular}{|l|l|}
\hline Panjang Interval Kelas $\rightleftarrows \begin{array}{l}\text { Skor Ideal : Banyaknya } \\
\text { Kelas Interval }\end{array}$ \\
Panjang Interval Kelas $\longrightarrow$ 22500: $5=4500$
\end{tabular}

Jumlah skor tanggapan responden terhadap keputusan untuk mengunjungi yaitu 7155 , maka tanggapan 250 responden terhadap lingkungan fisik organisasi (servicescape) adalah (7155 : 12500) $\times 100 \%=57 \%$. Hal ini secara kontinum termasuk dalam kategori rendah.

Responden adalah sebutan bagi pelanggan museum. Oleh karena itu teori dan konsep yang digunakan dalam penelitian ini, khususnya yang berkenaan dengan pengertian keputusan untuk mengunjungi menggunakan teori yang berasal dari keputusan pembelian.

Keputusan pembelian merupakan tahap dalam proses pengambilan keputusan pembelian, dimana konsumen benar-benar membeli produk. Pada tahap evaluasi, para konsumen membentuk preferensi atas merek-merek dalam kumpulan pilihan. Konsumen juga mungkin membentuk niat untuk membeli produk yang paling disukai.

Berdasarkan penjelasan tersebut maka dapat diambil kesimpulan bahwa keputusan untuk mengunjungi merupakan keterikatan respondeni terhadap layanan jasa atau dengan kata lain responden memiliki nilai loyalitas atau kesetiaan layanan jasa dari Museum.

\section{HASIL PENGUJIAN DAN PEMBAHASAN HIPOTESIS}

Hipotesis yang akan diuji adalah besarnya pengaruh lingkungan fisik organisasi (Servicescape) terhadap keputusan untuk mengunjungi Museum Negeri Sri Baduga Bandung Bandung pada responden Museum negeri Sri Banduga Bandung.

Pengaruh antar variabel ini menggunakan aplikasi software SPSS 13.00 for windows untuk mengetahui tingkat korelasi dan koefisien determinasi antar variabel berdasarkan hasil perhitungan dengan menggunakan teknik regresi linier dengan cara melihat korelasinya.

Untuk menguji variabel ini, akan dihitung nilai signifikan dari setiap variabel atau dapat juga membandingkan antara thitung dengan $t_{\text {tabel. }}$. Hasil uji statistik yang dilakukan dengan analisis regresi linier untuk mengetahui pengaruh antara variabel lingkungan fisik organisasi (Servicescape) terhadap keputusan untuk mengunjungi ini disajikan hasilnya dalam beberapa tabel dalam lampiran. Kemudian hasil perhitungan statistik yang diperoleh nilai korelasi ( $R$ Square), Nilai $F$ dan koefisien Regresi, yang akan diperlihatkan pada tabel-tabel berikut:

\section{Analisis Korelasi}

Tabel 7

Descriptive Statistics

\begin{tabular}{|c|c|c|c|}
\hline & Mean & $\begin{array}{c}\text { Std. } \\
\text { Deviation }\end{array}$ & N \\
\hline keputusan utk mengunjungi & 20.33 & 4.533 & 250 \\
servicescape & 50.63 & 11.972 & 250 \\
\hline
\end{tabular}

Sumber: Hasil Pengolahan Data 2008

Tabel 8

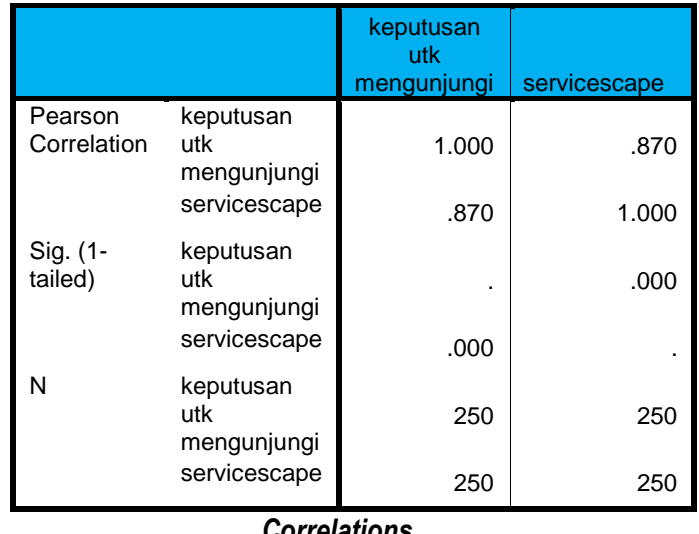

Correlations

Sumber: Hasil Pengolahan Data 2008 


\section{StrategiC}

Tabel 7 dan Tabel 8 di atas menunjukkan gambaran bahwa dari hasil uji regresi diketahui bahwa rata-rata keputusan untuk mengunjungi dari total 250 responden adalah 20,33 dan rata-rata servicescape dari total 250 responden adalah 50,63 . sedangkan hubungan antara servicescape dan keputusan untuk mengunjungi signifikan karena nilai $p=0,000$ atau $p<0.05$, dan nilai $r=$ 0,870 menunjukkan hubungan korelasi yang kuat.

Tabel 9

Variables Entered/Removed(b)

\begin{tabular}{|l|l|l|l|}
\hline Model & Variables Entered & $\begin{array}{l}\text { Variables } \\
\text { Removed }\end{array}$ & Method \\
\hline 1 & servicescape(a) & & Enter \\
\hline
\end{tabular}

a All requested variables entered.

b Dependent Variable: keputusan utk mengunjungi

Sumber: Hasil Pengolahan Data 2008

Berdasarkan Tabel 9 diatas yang termasuk pada Variable Entered/Removed adalah servicescape sebagai variabel independen (variabel bebas) dan keputusan untuk mengunjungi sebagai variabel dependen (variabel terikat).

Tabel 10

Model Summary (Nilai Korelasi R Square)

\begin{tabular}{|l|r|r|r|r|}
\hline Model & $\mathrm{R}$ & $\mathrm{R}$ Square & $\begin{array}{c}\text { Adjusted } \mathrm{R} \\
\text { Square }\end{array}$ & $\begin{array}{c}\text { Std. Error of the } \\
\text { Estimate }\end{array}$ \\
\hline 1 & $.870(\mathrm{a})$ & .758 & .757 & 2.236 \\
\hline
\end{tabular}

a Predictors: (Constant), servicescape

b Dependent Variable: keputusan utk mengunjungi

Sumber: Hasil Pengolahan Data 2008

Berdasarkan Tabel 10 model summary output SPSS 13.00 for windows di atas dapat diketahui bahwa korelasi atau hubungan antara variabel servicescape dengan variebel keputusan untuk mengunjungi memperoleh hasil sebesar 0,870 (positif) karena nilainya di atas 0,5 yang berarti korelasi antar variabel termasuk kategori sangat tinggi $(0,800-1,000) . \quad(R \times R)=R$ Square/koefisien determinasi adalah 0,758 (berasal dari 0,928 X 0,928). Dengan $\mathrm{R}$ Square sebesar 0,757 artinya $75,7 \%$ variasi dari keputusan untuk mengunjungi bisa dijelaskan oleh variasi dari servicescape, sedangkan sisanya $(100 \%-75,7 \%=$ $24,3 \%$ dijelaskan oleh variabel lainnya. StandarError of Estimate (SEE) adalah 1,888 lebih kecil dari standar deviasi yaitu 5,034 , maka model regresi layak digunakan.
Tabel 11

Uji Anova atau f Test

\begin{tabular}{|c|c|c|c|c|c|c|}
\hline Model & & $\begin{array}{l}\text { Sum of } \\
\text { Squares }\end{array}$ & df & $\begin{array}{l}\text { Mean } \\
\text { Square }\end{array}$ & $\mathrm{F}$ & Sig. \\
\hline \multirow[t]{3}{*}{1} & Regression & 3875.204 & 1 & 3875.204 & 774.894 & $.000(a)$ \\
\hline & Residual & 1240.234 & 248 & 5.001 & & \\
\hline & Total & 5115.438 & 249 & & & \\
\hline
\end{tabular}

a Predictors: (Constant), servicescape

b Dependent Variable: keputusan utk mengunjungi

Sumber: Hasil Pengolahan Data 2008

Tabel 11 di atas menunjukkan bahwa dari hasil Uji Anova atau $F$ Test didapat $F_{\text {hitung }}$ adalah sebesar 774.894 lebih besar dari $F_{\text {tabel }}$ sebesar 4,008 (yang didapat dari interpolasi data, yaitu dengan perhitungan (dk) $n-k-1=250-1-1=248 ; F_{\text {Tabel }}$ untuk $\mathrm{dk}=248$ adalah 3,882 ini dihitung sendiri karena tidak terdapat dalam tabel distribusi $F$, untuk lebih jelasnya dapat dilihat dalam lampiran). Bila dilihat dari $P$-Value diperoleh nilai sebesar 0,000 , nilai ini lebih kecil dari alphanya yaitu 0,05 , maka model regresi ini dapat dipakai untuk memprediksi keputusan untuk mengunjungi atau dengan kata lain bahwa servicescape dapat berpengaruh terhadap keputusan untuk mengunjungi.

Sedangkan untuk mengetahui derajat hubungan antara variabel $X$ (servicescape) dan variabel $Y$ (keputusan untuk mengunjungi) adalah dengan menggunakan rumus korelasi product moment, dimana data yang dimasukkan ke dalam rumus merupakan data interval yang dapat dilihat pada lampiran. Nilai-nilai data interval (MSI) tersebut diperoleh dengan menggunakan aplikasi Succ'97 pada program exel.

\section{Analisis Regresi Linear Sederhana}

Berdasarkan tabel koefisien, dengan menggunakan aplikasi sofware SPSS 13.00 for windows maka dapat diperoleh persamaan regresi linier antara kinerja iklan dan brand loyalty yang terlihat pada Tabel 12 di bawah ini.

\section{Tabel 12}

Koefisien regresi

Coefficients $^{3}$

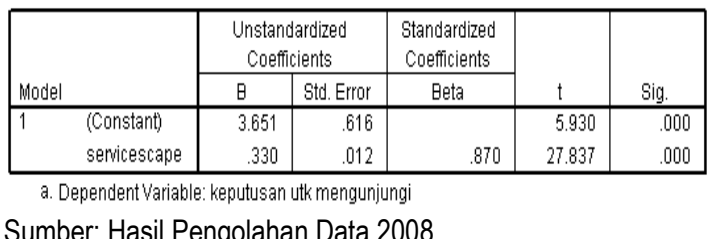

Sumber: Hasil Pengolahan Data 2008 
Nilai B Constant 3,651 menyatakan bahwa jika servicescape diabaikan, maka keputusan untuk mengunjungi adalah $3,651 \%$. Nilai $B$ kinerja iklan 0,330 menyatakan bahwa setiap penambahan servicescape sebesar 1,00, keputusan untuk mengunjungi akan meningkat sebanyak $0,330 \%$. Hal ini menerangkan bahwa kinerja iklan memiliki kontribusi yang cukup tinggi terhadap brand loyalty yaitu sebesar 0,330 dimana koefisien determinasi $\left(\mathrm{r}^{2}\right)$ yaitu 0,758 termasuk kategori cukup tinggi karena berada diantara $(0,600-0,800)$. Berdasarkan nilai $B$ constant dan $B$ servicescaoe pada Tabel 4.36 maka dapat dilihat bahwa persamaan regresi linier antara servicescape dan keputusan untuk mengunjungi dapat membentuk persamaan regresi, adapun persamaan regresinya adalah sebagai berikut:

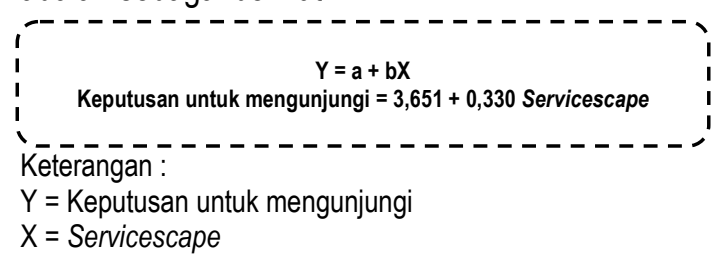

Berdasarkan persamaan regresi di atas, konstanta sebesar 3,651 menyatakan bahwa jika tidak ada servicescape $(X=0)$ maka keputusan untuk mengunjungi 3,651. Koefisien regresi 0,330 artinya setiap terjadi peningkatan servicescape akan meningkatkan keputusan untuk mengunjungi sebesar 0,330, dan sebaliknya jika terjadi penurunan servicescape akan menurunkan volume penjualan sebesar 0,330 .

Untuk lebih jelasnya, persamaan tersebut akan digambarkan ke dalam sebuah diagram garis regresi linier berikut ini:

\section{Normal P-P Plot of Regression Standardized Residual}

\section{Dependent Variable: keputusan utk mengunjungi}

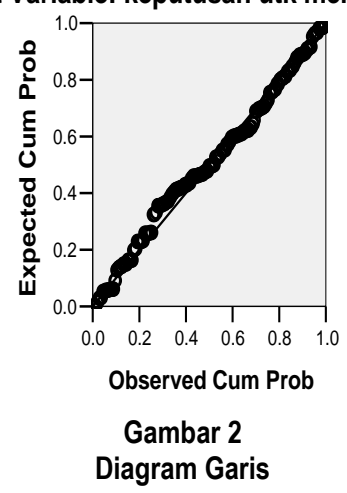

Gambar tersebut menunjukan bahwa data menyebar disekitar garis diagonal dan mengikuti arah diagonal. Maka, model regresi memenuhi asumsi normalitas.

\section{Analisis Determinasi}

Untuk mengetahui besarnya pengaruh variabel $X$ terhadap variabel $Y$, dapat diketahui melalui koefisien determinasi, adapun rumus yang digunakan oleh penulis adalah sebagai berikut:

$$
\begin{aligned}
\mathrm{Kd} & =r^{2} \times 100 \% \\
& =(0,870)^{2} \times 100 \% \\
& =75,8 \%
\end{aligned}
$$

Hasil perhitungan di atas menunjukkan bahwa besarnya Kd (koefisien determinasi) adalah $75,8 \%$ yang berarti bahwa perubahan data pada variabel $Y$ sebesar $75,8 \%$ dipengaruhi oleh perubahan pada variabel X. Sedangkan $24,2 \%$ dipengaruhi oleh faktor-faktor lain yang mempengaruhi besarnya keputusan untuk mengunjungi.

Hipotesis yang diuji yaitu pengaruh servicescape $(X)$ terhadap keputusan untuk mengunjungi $(\mathrm{Y})$. Untuk menguji signifikansi konstanta dari variabel $X$ diperoleh dari uji $t$ dengan hipotesis sebagai berikut:

$H_{o}: \rho \leq 0$,

Artinya tidak terdapat pengaruh yang positif dan signifikan servicescape terhadap keputusan untuk mengunjungi Museum Negeri Sri Baduga Bandung Bandung

$H_{1}: \rho>0$,

Artinya terdapat pengaruh yang positif dan signifikan servivescape terhadap keputusan untuk mengunjungi Museum Negeri Sri Baduga Bandung Bandung

Pengujian signifikansi dilakukan dengan membandingkan nilai tabel dengan harga thitung, untuk taraf kesalahan $5 \%$ uji satu pihak dengan $\mathrm{dk}$ $=n-2$, dengan menggunakan aplikasi software SPSS 13 maka diperoleh $t_{\text {hitung }}$ sebesar $=19,337$.

Berdasarkan hasil perhitungan, maka diperoleh $t_{\text {hitung }}$ sebesar $=19,337$; sedangkan dalam $t_{\text {tabel }}$ pada taraf signifikansi $=0,05$ dengan derajat kebebasan (dk) $N-2=250-2=248$, tidak terdapat dalam tabel sehingga perlu dilakukan interpolasi antara $\mathrm{dk}=120 \mathrm{dan} \mathrm{dk}=$ tak hingga yang dapat dilihat pada lampiran, sehingga diperoleh tabel sebesar 1,645. Dengan demikian, maka $t$ hitung $=27,837>t$ tabel $=1,645$ artinya hipotesis nol $\left(\mathrm{H}_{0}\right)$ ditolak, dengan kata lain hipotesis yang diajukan peneliti diterima yaitu: 
Keputusan untuk mengunjungi dipengaruhi secara positif dan signifikan oleh Servicescape.

Adapun rangkuman hasil pengujian hipotesis dapat dilihat pada Tabel 13 berikut ini:

Tabel 13

Rangkuman Hasil Uji Hipotesis

\begin{tabular}{|c|c|c|c|}
\hline Hipotesis & $t_{\text {hitung }}$ & $t_{\text {tabel }}$ & Keputusan \\
\hline $\begin{array}{lr}\text { Terdapat } & \text { pengaruh } \\
\text { Servicescape } & \text { terhadap } \\
\text { Keputusan } & \text { untuk } \\
\text { mengunjungi } & \text { Museum } \\
\text { Negeri Sri } & \text { Baduga } \\
\text { Bandung Bandung }\end{array}$ & 27,837 & 1,645 & $\begin{array}{c}\mathrm{H}_{0} \text { ditolak } \\
\text { dan } \\
\mathrm{H}_{1} \text { diterima }\end{array}$ \\
\hline
\end{tabular}

Sumber: Hasil Pengolahan Data

\section{IMPLIKASI HASIL PENELITIAN}

Hasil perhitungan analisis data dari variabel lingkungan fisik organisasi (servicescape) dan keputusan untuk mengunjungi Museum yang telah dilakukan, maka dapat diketahui bahwa lingkungan fisik organisasi (servicescape) berpengaruh secara positif terhadap keputusan untuk mengunjungi Museum Negeri Sri Baduga Bandung

Dari hasil penelitian diperoleh koefisien korelasi 0,870 antara variabel lingkungan fisik organisasi (servicescape) dengan variabel keputusan untu mengunjungi (Y) memiliki hubungan yang termasuk sangat tinggi. Selain itu lingkungan fisik organisasi (servicescape) juga memiliki pengaruh yang positif terhadap keputusan untuk mengunjungi, hal ini terbukti dengan hasil perhitungan koefisien determinasi yaitu dengan mengkuadratkan koefisien korelasi $\mathrm{r}^{2} \times 100 \%=$ $(0,870)^{2} \times 100 \%$ diperoleh hasil sebesar $75,8 \%$ yang berarti bahwa perubahan variabel keputusan untuk mengunjungi sebesar $75,8 \%$ dipengaruhi oleh lingkungan fisik organisasi (servicescape). Sedangkan faktor lain sebesar $24,4 \%(100 \%$ $75,8 \%$ ) yang mempengaruhi nilai keputusan untuk mengunjungi dijelaskan oleh sebab-sebab lain.

Adapun untuk mengetahui uji probabilitas atau uji keputusan untuk mengunjungi, maka dapat diketahui melalui Tabel Anova atau $\mathrm{F}$ test dengan besar $F$ hitung, yaitu sebesar 774,894 dengan tingkat signifikansi 0,000 karena probabilitas $(0,000)$ jauh lebih kecil dari 0,05 , maka $\mathrm{H}_{0}$ ditolak, atau koefisien regresi signifikan atau lingkungan fisik organisasi (servicescape) benar-benar berpengaruh secara signifikan terhadap keputusan untuk mengunjungi. Walaupun demikian, jika pada proses uji koefisien regresi, ternyata konstanta dinyatakan tidak valid, maka koefisien regresi $(X)$ adalah valid, sehingga model persamaan regresi tetap dapat dipakai untuk memprediksi keputusan untuk mengunjungi.

Pengambilan keputusan pengujian hipotesis dilakukan dengan membandingkan $t_{\text {hitung }}$ denga $t_{\text {tabel. }}$ Perhitungan uji signifikasi dengan menggunakan alpha 0,05 pada uji satu pihak dengan derajat kebebasan (dk) $n-2, d k=250-2$ $=248$ diperoleh hasil perhitungan tabel sebesar 0,3882 . Dengan demikian maka $\mathrm{dk}=248$ diperoleh $t_{\text {hitung }}$ dan $t_{\text {tabel }}$ dengan taraf kesalahan 0,05 , berdasarkan ketentuan hipotesis diterima jika thitung $>t_{\text {tabel, }}$ maka diketahui bahwa harga $t_{\text {hitung }}$ lebih besar dari tabel $(19,008>0,3882)$. Sehingga dapat disimpulkan bahwa koefisien korelasi antara variabel lingkungan fisik organisasi (servicescape) dengan keputusan untuk mengunjungi memiliki hubungan yang signifikan.

Pernyataan tersebut diperoleh melalui pengujian hipotesis yang menggunakan metode regresi linier. Regresi tersebut ditunjukkan dengan perolehan keputusan untuk mengunjungi sebesar 3,651 ditambah 0,330 dari lingkungan fisik organisasi (servicescape) atau $(Y=3,651+$ 0,330X). Dimana hasil tersebut dapat diartikan, bila nilai setiap penambahan 1\% lingkungan fisik organisasi (servicescape) akan meningkatkan keputusan untuk mengunjungi sebesar $0,330 \%$. $\mathrm{Hal}$ ini menerangkan bahwa lingkungan fisik organisasi (servicescape) memiliki kontribusi yang cukup tinggi terhadap keputusan untuk mengunjungi yaitu sebesar 0,330 , dimana koefisien determinasinya $\left(r^{2}\right)$ yaitu 0,758 , termasuk kategori cukup tinggi berada diantara $(0,600$ 0,800 ).

Koefisien korelasi yang bernilai positif menunjukkan bahwa hubungan antara kedua variabel tersebut berbanding lurus, artinya jika perusahaan meningkatkan lingkungan fisik organisasi (servicescape) dalam bisnisnya, maka dapat diprediksi bahwa keputusan untuk mengunjungi pun akan naik. Namun, sebaliknya jika perusahaan tidak meningkatkan lingkungan fisik organisasi (servicescape), maka keputusan untuk mengunjungi pun dapat menurun bahkan lebih buruk untuk jangka panjang.

Lingkungan fisik organisasi (servicescape) merupakan lingkungan fisik dimana jasa disampaikan dan dimana perusahaan dan konsumennya berinteraksi, serta setiap komponen 
tangible yang memfasilitasi penampilan yang dipakai untuk berkomunikasi atau mendukung peran jasa tersebut (Yazid, 2005:20). Jasa bersifat intangible sehingga sulit untuk dievaluasi maka lingkungan fisik memberikan tanda-tanda, misalnya bagaimana kualitas jasa tersebut.

Pengunjung adalah sebutan bagi pelanggan museum. Oleh karena itu teori dan konsep yang digunakan dalam penelitian ini, khususnya yang berkenaan dengan pengertian keputusan untuk mengunjungi menggunakan teori yang berasal dari keputusan pembelian.

Keputusan pembelian merupakan tahap dalam proses pengambilan keputusan pembelian, dimana konsumen benar-benar membeli produk. Pada tahap evaluasi, para konsumen membentuk preferensi atas merek-merek dalam kumpulan pilihan. Konsumen juga mungkin membentuk niat untuk membeli produk yang paling disukai.

Berdasarkan beberapa pendapat para ahli mengenai pengaruh lingkungan fisik organisasi (servicescape) terhadap keputusan untuk mengunjungi di atas dapat kita ambil kesimpulan bahwa upaya menumbuhkan kesan menarik merupakan tujuan utama bagi perusahaan dalam melakukan program peningkatan layanan jasa karena kesan menarik merupakan gambaran total dari pikiran responden terhadap layanan jasa.

Kemampuan lingkungan fisik organisasi (servicescape) untuk mempengaruhi perilaku konsumen dalam memutuskan membeli layanan jasa tertentu tergantung pada sikap responden terhadap lingkungan fisik organisasi (servicescape). lingkungan fisik organisasi (servicescape) yang diminati akan mendatangkan sikap positif terhadap jasa dan tanggapan positif terhadap jasa dan memutuskan untuk membeli jasa tersebut. Sedangkan lingkungan fisik organisasi (servicescape) yang tidak diminati dapat menimbulkan sikap negatif dan akhirnya dapat menurunkan kesan jasamaupun perusahaan sehingga dapat menurunkan loyalitas responden dan kepuasan responden yang berdampak kepada penurunan loyalitas jasa.

\section{SIMPULAN DAN SARAN}

\section{Simpulan}

Berdasarkan hasil penelitian dan pembahasan, maka dapat disimpulkan bahwa:

1. Tanggapan terhadap lingkungan fisik organisasi (Servicescape) hampir seluruhnya responden menyatakan sedang. Hal ini dapat dilihat dari ke delapan indikator yang diurutkan dari mulai yang tertinggi sampai terendah, yaitu air quality, design interior, equipment, surrounding environment, parking, landscape, lay out dan design exterior

2. Tanggapan terhadap keputusan untuk mengunjungi Museum Negeri Sri Baduga Bandung sebagian besar responden menyatakan sangat rendah. Hal ini dapat dilihat dari ke empat indikator yang diurutkan dari mulai yang tertinggi sampai terendah yaitu, frekuensi kunjungan, waktu kunjungan, pilihan koleksi museum dan pilihan nama museum.

3. Pengaruh Lingkungan fisik organisasi (Servicescape) (X) terhadap keputusan untuk mengunjungi $(Y)$ cukup tinggi.

\section{Saran}

Berdasarkan hasil dan pembahasan penelitian dapat direkomendasikan pada Museum Negeri Sri Baduga Bandung dalam rangka meningkatkan jumlah pengunjungnya adalah sebagai berikut :

1. Merubah desain eksterior museum agar tampak lebih menarik, dengan cara memberikan gambar-gambar atau relief yang berhubungan dengan kebudayaan di dinding bangunan museum, agar dapat menarik minat masyarakat untuk mau berkunjung ke Museum Negeri Sri Baduga Bandung.

2. Penataan cahaya yang baik, dengan cara memasang lampu yang lebih tersng dan beragam agar dapat memberikan nilai tambah bagi pengunjung yang melihatnya.

3. Pengawasan keamanan di lingkungan sekitar yang lebih diperketat, dengan cara menambah personel keamanan (satpam) serta memasang alarm agar pengunjung dapat merasa lebih aman dan nyaman dari gangguan kawasan (pihak) luar museum ketika berkunjung ke Museum Negeri Sri Baduga Bandung.

4. Penyediaaan peralatan yang lebih lengkap, dengan cara menyediakan sarana pendukung banda-benda pameran sehingga pengunjung dapat merasa lebih puas melihat benda-benda pameran Museum Negeri Sri Baduga Bandung.

5. Merubah desain interior museum agar tampak lebih menarik, dengan cara memasang beberapa lukisan di dinding museum. 
6. Perubahan nama museum, dengan cara memakai nama yang unik serta lebih mencerminkan budaya Jawa Barat.

7. Perubahan logo museum, dengan cara memakai kata yang padat, singkat dan jelas serta lebih mudah diingat oleh masyarakat sehingga mau berkunjung ke Museum Negeri Sri Baduga Bandung.

8. Melakukan perawatan yang teratur terhadap benda-benda pameran museum yang ada serta menambah koleksi museum sehingga pengunjung dapat mengetahui lebih jauh mengenai kebudayaan provinsi Jawa Barat.

\section{DAFTAR PUSTAKA}

Buchari Alma. 2000. Manajemen Pemasaran dan Pemasaran Jasa. Bandung:CV. Alfabeta

Buchari Alma. 2004. Manajemen Pemasaran dan Pemasaran Jasa. Bandung:CV. Alfabeta

Buchari Alma. 2005. Kewirausahaan. Bandung:CV. Alfabeta

Cravens.David W. 1998. Pemasaran Strategis. Jakarta: Erlangga.

Fandy Tjiptono. 2006. Pemasaran Jasa. Malang: Bayumedia Publishing

Harun Al-Rasyid. 1994. Teknik Penarikan Sampel dan Penyusunan Skala. Bandung: Prodi Ilmu Sosial BKU Sosiologi Antropologi Program Pasca Sarjana UNPAD.

Husein Umar. 2001. Riset Pemasaran dan Perilaku Konsumen. Jakarta: Business Research Centre, Jakarta.

Komaruddin Sastradipoera . 2005. Mencari Makna Dibalik Penulisan Skripsi, Tesis, dan Disertasi. Bandung: Kappa-Sigma.

Kotler, Amstrong. 2004. Dasar-Dasar Pemasaran. Jakarta: Salemba Empat.

Kotler, Philip dan Gary Amstrong . 2000. Principle of Marketing. Prentice Hall,Inc.

Kotler, Philip. 2003. Marketing Management an Asian Perspective. Singapore: Pearson Prentice Hall.

Kotler, Philip. 2005. Manajemen Pemasaran. Edisi Kedua. Indonesia : PT. Indeks Kelompok Gramedia.

Kotler, Philip. 2005. Manajemen Pemasaran. Edisi Pertama. Indonesia : PT. Indeks Kelompok Gramedia.

Masri Singarimbun. 1995. Metode Penelitian Survei, Jakarta: LP3S.

Pina. Jose M.. 2004. Modelling The Impact of Services Brand Extensions on Corporate Image. Journal of Marketing
Sudjana. 2004. Metode Statistik untuk Tata Niaga I dan II. Bandung: Tarsito.

Sugiyono. 2005. Metodologi Penelitian Bisnis. Bandung: CV. Alfa Beta

Suharsimi Arikunto. 2003. Prosedur Penelitian Suatu Pendekatan Praktek. Jakarta: Rineka Cipta.

Sutisna. 2002. Perilaku Konsumen dan Komunikasi Pemasaran. Bandung: Rosda Karya.

Sutodjo Siswanto. 2004. Membangun Citra Perusahaan. Jakarta: Danar Mulia Pustaka

Uma Sekaran. 2006. Research Methods For Business (Metodologi Penelitian Untuk Bisnis). Jakarta: Salemba Empat.

Usman Husaini. (2006). Pengantar Statistika. Jakarta: Bumi Aksara 